\title{
On the Methodological Unity of Post-Industrial and Sustainable Development as the Environment Preservation Imperative
}

\author{
Daniela Marasova ${ }^{1}$, Massimo Ligatto ${ }^{2}$, Daniel Cassati ${ }^{2}$, and Vladimir Zolotukhin ${ }^{1,}{ }^{*}$ \\ ${ }^{1}$ Technical University of Kosice, Faculty of Mining, Ecology, Process Control and Geotechnologies, \\ Letná 9, 04200 Kosice, Slovak republic) \\ ${ }^{2}$ University of Cagliari, 09124 Via Università 40, Cagliari, Italy \\ ${ }^{3}$ T.F. Gorbachev Kuzbass State Technical University, Department of history, philosophy and social \\ sciences, 65000028 Vesennya st., Kemerovo, Russia
}

\begin{abstract}
Each stage of the economic development of any society is associated with the consumption of natural resources. Thus, the impact of human society on the environment determines the environmental conditionality of the economy. The problem of economy - the maximum satisfaction of needs - becomes the central problem of ecology, as the development of civilization has caused a large volume of resources' consumption. National economies can be at one of the following development stages: traditional, industrial, post-industrial society. Each stage is characterized by a certain state, the structure of economy, the type and amount of used resources, the attitude to the natural environment and, accordingly, the type of ecological and economic development. In an industrial society, the environmental conditioning of the economy is associated with the use and minimization of resource consumption in order to increase the economic efficiency, but not with understanding that the resources are exhaustible and non-renewable. Therefore, when moving to the postindustrial stage of development, it is important to understand its connection with sustainable development, which consists in synchronizing the innovative development of the productive forces of industry and the "green" nature-saving technologies.
\end{abstract}

\section{Introduction}

Primary industrialization meant the transition from manual to machine labor, when the worker became free from direct impact on the subject of labor. Machines are three-link means of labor, including the engine, transmission and working tools. This industrialization is accompanied by four technological revolutions. In the 18th-19th centuries the steam engine, steam locomotive and steamer transformed the textile industry and transport in Britain, and then throughout Europe. The replacement of charcoal with hard coal created a new metallurgy. Electric and gasoline-diesel engines, created in the US and Germany in the XIX century, allowed organizing industrial production in any region. In the United States at

*Corresponding author: zvm64@mail.ru 
the beginning of the 20th century, the third, conveyor revolution, which created huge trusts and mass production of cars and other equipment, took place. Oil replaced coal as the main source of energy. Finally, at the end of the 20th century, the spread of the Internet, mobile communications, and telecommunications made the machine production global, involved in the industrialization the multi-billion population of the southern and eastern regions of the planet.

Primary industrialization of commodity economies developed only in the late XIX early XX centuries. Its characteristic features are: mass attraction of rural population to cities, involvement in the economic circulation of previously unused natural resources on the basis of broad railway construction, catching up development - the purchase of technologies already developed abroad due to credits and export of raw materials. In the Soviet years, these characteristics were supplemented by the extensive use of forced labor, the seizure of the surplus product of the agricultural complex, and orientation mainly on the development of the military industry.

Today, ongoing industrialization has entered a new stage, called post-industrial development. Despite the growth of non-material production, energy is increasingly extracted in the world (by $4-5 \%$ annually), emissions to the atmosphere and the world ocean are increasing (by 2-3\% annually). Consequently, the transition to a post-industrial economy should be viewed in a methodological unity with sustainable development.

\section{Materials and Methods}

The ideas of sustainable development have their origin in the Report of the World Commission on Environment and Development. The report demonstrates for the first time an attempt to comprehensively analyze the negative externalities of contemporary social and economic development. In opening remarks, the chairman of the commission, Gro Harlem Brundtland, noted: "When in 1982, for the first time the powers of our Commission were discussed, there were people who wanted it to be limited by the consideration of only "environmental issues", this would be a serious mistake. The environment does not exist separately from human activities, from its aspirations and needs, and therefore attempts by some political circles to protect it in isolation from human anxieties give the very word "environment" a touch of naivety." Here we can note the support of the ideas derived from the results of the Stockholm Conference of 1972, namely, the unity of man and the environment and the responsibility for harming nature [1].

According to the above-mentioned report, sustainable development "is a development that meets the needs of the present, but which does not pose a threat to the ability of future generations to meet their own needs." At the same time, not only environmental, but also social, economic, political and other needs of humanity were examined. In our opinion, the Brundtland Commission Report highlighted the main features of sustainable development as a concept of the existence of mankind on the Earth. They can be described as follows: the consumption of natural resources should not exceed the natural limitations caused by the parameters of the natural environment of our planet. To implement this global imperative, a number of approaches were proposed reflecting a modern palette of experience and new ideas of environmental policy.

The most well-known document related to sustainable development is "Agenda of the XXI century" adopted by the United Nations Conference on Environment and Development (Rio de Janeiro, June 1992) [2]. It should be noted that sustainable development appears here as the main functional category. This and other documents adopted in Rio de Janeiro, after their signing by the heads of state or government of practically all countries of the world, have become the basis for global environmental policy. 
Further, the main provisions of sustainable development, methods, instruments and directions of interaction of the parties concerned were discussed at major international meetings. The most significant among them were meetings in Johannesburg (2002), Marrakech (2003) and San Jose (2005) (Table 1).

Table 1. Chronology of international discussions of sustainable development.

\begin{tabular}{|c|c|c|c|}
\hline Year & Place & Discussed issues and proposed solutions & $\begin{array}{c}\text { Developed and adopted } \\
\text { documents }\end{array}$ \\
\hline 2002 & $\begin{array}{c}\text { Johannesburg, } \\
\text { South Africa }\end{array}$ & $\begin{array}{l}\text { The problems of differentiation of countries } \\
\text { and regions of the world in terms of living } \\
\text { standards, ecological situation, political } \\
\text { freedoms }\end{array}$ & $\begin{array}{l}\text { Plan to implement the } \\
\text { decisions of the UN } \\
\text { World Summit on } \\
\text { Sustainable } \\
\text { Development }\end{array}$ \\
\hline 2003 & $\begin{array}{l}\text { Marrakech, } \\
\text { Morocco }\end{array}$ & $\begin{array}{l}\text { The establishment of informal task groups on } \\
\text { various aspects of sustainable consumption } \\
\text { and production, with the participation of } \\
\text { experts from developed and developing } \\
\text { countries to carry out tasks in a 10-year period }\end{array}$ & \multirow{3}{*}{$\begin{array}{l}\text { Formation of target } \\
\text { groups within the } \\
\text { Marrakesh Process }\end{array}$} \\
\hline 2005 & $\begin{array}{c}\text { San Jose, Costa } \\
\text { Rica }\end{array}$ & $\begin{array}{l}\text { The creation of the "Marrakech Process" } \\
\text { groups on sustainable lifestyles (Sweden), } \\
\text { public involvement in sustainable } \\
\text { development management (Switzerland) }\end{array}$ & \\
\hline 2007 & $\begin{array}{l}\text { Stockholm, } \\
\text { Sweden }\end{array}$ & $\begin{array}{l}\text { The monitoring of the Marrakech Process, the } \\
\text { creation of education groups (Italy), } \\
\text { construction (Finland) and food production } \\
\text { (Great Britain) }\end{array}$ & \\
\hline 2011 & $\begin{array}{l}\text { New York, } \\
\text { USA }\end{array}$ & $\begin{array}{l}\text { Thematic debate on the "green economy", } \\
\text { discussion of the concept of green economy as } \\
\text { an economic tool for the formation of } \\
\text { sustainable development }\end{array}$ & \\
\hline 2012 & $\begin{array}{c}\text { Rio de Janeiro, } \\
\text { Brazil }\end{array}$ & $\begin{array}{l}\text { Summing up the results of } 20 \text { years of work on } \\
\text { the formation of sustainable development in } \\
\text { the world }\end{array}$ & $\begin{array}{l}\text { The Declaration "The } \\
\text { Future We Want" }\end{array}$ \\
\hline
\end{tabular}

The meeting in Rio de Janeiro ("Rio+20") in 2012 was a landmark event, the main purpose of which was to summarize the results of international cooperation and the work of individual countries in the field of sustainable development [3-4]. As it was noted in the final document of the conference "The Future We Want", "... since 1992, the progress achieved in certain areas was insignificant and it was necessary to face difficulties in integrating the three components of sustainable development, which were further aggravated by the financial, economic, food and energy crises, which pose the threat to the achievement of sustainable development goals by all countries, especially developing ones" $[5]$.

The problems associated with the retaining of poverty, unsustainable production and consumption and the state of natural ecosystems have been especially highlighted. As a result, there is a significant change in the problems of sustainable development - from the problems of co-evolution of nature and man to the problems of the development of world society, complicated by economic, social and environmental differentiation of countries.

Summarizing all mentioned above, it is worth noting that sustainable development is one of the most urgent problems of all the world community. The problems of sustainable 
development are of great importance for the domestic science, since the preservation of the dynamic equilibrium of the regional social-and-ecological and economic systems guarantees security, stability, reliability, and the integrity of development.

The post-industrial economy existed in the developed countries by the beginning of the XXIst century is often called innovative. However, the elements of the global market and the radical liberal policy have turned industrial capitalism not into an innovative one, but into a rent-and-debt policy. The main source of GDP growth instead of the increase in the number of labor, the volume of industrial capital and the natural resources used was not the development and effective use of the social productive forces of knowledge economy, but the extraction of rent - an additional cost associated with the monopoly of material, intellectual and organizational resources, the development of nonproductive but financial services. STP is not market-based by nature, because its effect cannot be reliably predicted either by nature, by volume, or by the timing of receipt. Financial speculation on securities and currency brings immeasurably greater profits, and trade-intermediary services are much more reliable in their profitability than innovations.

The USA receives three main types of rents: financial (emission of the world reserve currency and securities bought up by foreign investors), technological (patent monopoly), migration (more than half of the degrees in mathematics and natural sciences are from other countries). Russia survives at the expense of natural rents (the cost of producing one barrel of oil averages $\$ 10$, and the export price is much higher), while using the administrative and corruption mechanism to withdraw entrepreneurial and personal income from monopoly prices and restrict competition. Developing countries use social and environmental rent, organizing mass production with minimal expenditures on social security and environmental protection [6].

The transformation of industrial capitalism into rental-debt in a number of countries was accompanied by de-industrialization, the transfer of production to low-wage countries. This led to an increase in public debt, budget deficit and unemployment (in the EU it exceeded $11 \%$, and among youth in a number of countries - $40 \%$ ), increased social differentiation, the crisis of culture and system of basic values. According to the Bureau of Labor Statistics, the United States lost 9 million jobs with a payment of \$ 14-21 per hour (April 11, 2013). In 2007-2013 years the number of middle-class accountants, cashiers, computer operators, secretaries, etc. has fallen by 2 million. $79 \%$ of the 5 million new jobs offer payment below $\$ 14$ per hour. The income gap of the $10 \%$ of the richest and poorest citizens, according to official statistics in the US, increased to 16 , in Russia to 16.5 , and in the Nordic countries which did not experience de-industrialization is only 2-5 times [7-8].

\section{Results and Discussion}

The new industrialization means a transition from machine to robotic production. A flexible automated complex is a four-link means of labor, which includes computer-based scanning and control software along with the machine. This radically changes the content and working conditions, several times increasing its effectiveness. In Russia, according to the estimates of the Ministry of Economic Development (10.04.13), it is necessary to increase labor productivity by 1.5 times (according to the OECD it is $35.7 \%$ of the US level and 43 $49 \%$ - from the level of Estonia, Hungary and the Czech Republic), otherwise after 5-7 years, the country is threatened with a collapse of consumption, a devaluation of the ruble and a jump in inflation. The new industrialization requires the creation and modernization of 25 million jobs of efficient and well-paid work. Open software and extensive use of 3D printers will allow the employee to prepare the models of new products that meet specific customer needs, and programs for managing his robotic complex. The mechanical 
processing of the object of labor is replaced by physic-chemical and biological technologies that change its composition and structure.

The radical transformation of small and medium-sized businesses will supplant giant hierarchical corporations. In the cost of production, the share of costs for the transportation of huge amounts of raw materials will decrease and the share of costs for information, energy, and wages of mainly non- hired employees, but independent freelancers under civil-law contracts, will increase. The object of new industrialization is not only high-tech production, but also traditional industries, services, agribusiness, developing new technologies.

The new industrialization means a transition from industrial and rental-debt to an innovative economy. This means a change in the structure of factors and the quality of economic growth, the predominant form of capital (from private funds and objects of labor in the industrial economy and unregulated finance under modern conditions to the development of innovative, human, social and organizational capital), the predominant type of firms (from autonomous corporations and global financial groups controlling TNCs, to interregional supply chains and creating value, clusters, etc.), forms of competition (from the general competition for costs reduction and increase the scale of industrial production, from fair competition restrictions imposed by the global financial institutions and local mafia clans for joint innovation and investment projects and strategic alliances competing companies with a flexible system of contracts and pricing). Infrastructure becomes a key and limited market economy sector based on public-private partnerships. The production of services does not interfere with the production of material goods, but integrates with it: industrial firms perform system integration, engineering, consulting, informationeducational and other high-tech services.

The new industrialization is fundamentally different from the primary in its content (replacement of engine labor by robotic), sources (innovation, not the involvement of free labor and natural resources), efficiency criteria (productivity growth and quality of life, not GDP valuation), methods of implementation (mass entrepreneurship, not the execution of state teams). In developed countries, its basis is the development of high-tech production of goods and services, inseparable from R \& D centers, the transition from mass production of standard products to the satisfaction of individual consumer preferences, the organization of global value chains [1]. Rapidly developing countries, as shown by the World Bank study [2], are shifting from the export of predominantly low- and medium-tech mass products to the creation of 100 million new high-tech jobs oriented primarily to the domestic market. In India, this revolution is accompanied by the democratization of the command and control regime of management [3], and in China - a radical reform of education, infrastructure, social networks, land ownership and finance [4].

The new industrial policy, the refusal of the state from the majority of permissive and supervisory functions, the development of strategic goal-setting of the federal and local authorities based on public-private partnership, the replacement of mass imports of unskilled labor force by the system of updating the organization and production technology are of special importance for Russia.

\section{Conclusion}

Ecologization of the economy presupposes changes in the economy aimed at reducing its environmental intensity, pollution, and environmental degradation. Today it is necessary to take into account the new factor of economic growth - ecological. There comes understanding that natural resources are exhaustible and, in most cases, they are not renewable. Accordingly, the environmental conditionality of the economy implies the use of natural resources and their minimization in order to reduce the impact on the 
environment. The process of post-industrialization is connected with the achievement of sustainable economic development, which is due to the structural change in the economy. Structural reorganization of the economy will reduce the natural resource intensity of manufactured products, reduce the burden on the environment, and reduce the overall need for natural resources. The essence of economic reform is a decrease in the share of primary and secondary sectors in the economy (the development of which was specific for the technogenic type) and an increase in the share of the tertiary economy, that is, the services sector and knowledge-intensive industries. With increasing the influence of service sector and knowledge-intensive industries, the society still has needs for products from the extractive, processing and other branches of the economy.

So, when developing resource-saving technologies, the resource intensity of the products will decrease. This will lead to a change in the economic indicator, such as production costs, and will affect the environment as a reduction in the volume of natural resource extraction. The replacement of materials and products with more environmentally friendly products will lead to an improvement in the quality of the products produced, because environmentally friendly products are quality products.

Thus, as a result of the development of the tertiary economy, the anthropogenic load on nature must decrease, thereby ensuring sustainable economic development, on the basis of which a postindustrial society is formed.

\section{References}

1. P. Marsh, The new industrial revolution: consumers, globalization and the end of mass production (River Pub., London, 2012)

2. S. Lin, From flying gees to leading dragoons: new opportunities and strategies for structural transformation in developing countries (The World Bank, Washington, 2011)

3. S. Majunmar, India's late, late industrial revolution: democratizing entrepreneurship (Discovery, Cambridge, 2012)

4. F. Wang, The new Chinese economy: dynamic transitions into the future (Fisher's, New York, 2012)

5. M., Prokudina, O. Zhironkina, O. Kalinina, M. Gasanov, F. Agafonov, E3S Web of Conferences, 21,04003 (2017)

6. S. Zhironkin, M. Gasanov, G. Barysheva, E. Gasanov, O. Zhironkina, G. Kayachev, E3S Web of Conferences, 21, 04002 (2017)

7. S. Montero-Martínez, M. García de Quesada, Perspectives, 11:4, 293-314, (2010)

8. S.A. Zhironkin, K.A. Kolotov, O.V. Zhironkina, Economics and Innovation Management, 1, 4-16 (2017) DOI: 10.26730/2587-5574-2017-1-4-16 